\title{
KRYZYS ROSYJSKI I KIERUNKI WYJŚCIA W ŚWIETLE PRAC INSTYTUTU EURAZES
}

\author{
Iwona Massaka*
}

\begin{abstract}
THE RUSSIAN CRISIS AND THE DIRECTIONS TO EXIT FROM, IN LIGHT OF THE WORKS OF EURAZES INSTITUTE
\end{abstract}

\begin{abstract}
Works of analysts centered in the EurAzES Institute (EI), among them the dissertation by Vladimir Tamak on modernization of the Russian Federation (2012) and the anonymous "Global Project Russia" (2011), prove the vitality of the Eurasian idea in the RF (Russian Federation) and its political potential. Tamak's reformatory postulates, as well as, in a lesser degree, the ones of other scholars and activists from the circle of EI, are integrated with the negative opinion on political and social reality in the $\mathrm{RF}$ after 1993. The analysis of causes and prospective results of the crisis is directed by the thesis about the Russian and global oligarchic involvement. EI's neo-Eurasian reformatory projects, promoted as innovative, and the only ones among other modernizing programs announced in the recent years, constitute a compilation of selected elements of classical Eurasianism (i.a. idiocracy, organic democracy, anti-Occidentalism, Orthodox traditionalism), a contemporary version of Eurasianism elaborated by L. Gumilov (i.a. relative autarchy), and neo-Eurasianism by A. Dugin (i.a. vision of the future of the RF as Eurasia's heartland; non-European model of development of Eurasian industry).
\end{abstract}

- KEYWORDS

modernization in the Russian Federation, EurAzES Institute, oligarchy, integration, neo-Eurasianism

* Uniwersytet Mikołaja Kopernika w Toruniu, Wydział Politologii i Studiów Międzynarodowych. 
Okres prezydentury Dmitrija Miedwiediewa (lata 2008-2012) wypełniły głównie działania konserwujące porządek wprowadzony przez prezydenta Federacji Rosyjskiej Władimira Putina. Według określenia politologa Lilii Szewcowej Miedwiediew pełnił rolę imitatora i miestobliustitiela ${ }^{1}$. Rosyjska uczona twierdzi, że jako prezydent FR i jako dyrektor Instytutu Aktualnego Rozwoju (Instituta Sowriemiennogo Razwitija) zasłynął jako nieudolny lub/i fałszywy reformator. Rzeczywiście, wygłoszone przez niego w 2010 roku dwa cykle referatów na temat planowanych reform (pierwszy zatytułowano „Rosja w XXI wieku: obraz upragnionego jutra”, drugi - „Zwrot ku przyszłości. Strategia 2012”) nie pociągnęły za sobą istotnych zmian w sferze społecznej, ekonomicznej i politycznej. Rozczarowanie przyniosły także inne promowane przez rząd rosyjski inicjatywy zwiastujące reformy. Szumnie zapowiadany zespół ekspertów zdolnych do opracowania „klarownej strategii rozwoju pokryzysowego"2 ${ }^{2}$ pozostał jedynie listą nazwisk sporządzoną przez wicepremiera Igora Szuwałowa, sama zaś strategia rozwoju społeczno-ekonomicznego FR ustalona do końca 2020 roku jak dotąd wydaje się jeszcze jednym dokumentem o znaczeniu formalnym, fasadowym. Nie mniej bezpłodne są promodernizacyjne usiłowania rozproszonej w około dwudziestu formacjach nacjonalistycznych lewicy rosyjskiej. Przybierają one głównie postać publikacji, często zbiorowych, chętnie, choć nie zawsze w sposób uzasadniony, nazywanych projektem. Przykładem tego rodzaju twórczości jest obszerny wydany anonimowo „Projekt Siergiejewski” (na cześć Siergieja Radoneżskiego. Znany także jako „Doktryna Rosyjska”) napisany w Centrum Dynamicznego Konserwatyzmu, utworzonym w 2005 roku przez Andrieja Kobjakowa, Witalija Awierjanowa i Władimira Kuczerjenkę (występującego pod pseudonimem „Kałasznikow”) ${ }^{3}$. Warto także zwrócić uwagę na „Projekt Rosyjski” opracowany

1 Słowo to oznacza strażnika tronu, na którym zasiada zwyczajowo patriarcha Cerkwi prawosławnej w krótkim okresie między śmiercią dotychczasowego przywódcy Cerkwi, a wyborem nowego. Zob. W. Radziwinowicz, Co zostanie po Miedwiediewie, „Gazeta Wyborcza”, 7.05.2012.

${ }^{2}$ W strategii znamiennie nazwanej pokryzysową (a nie np. antykryzysową) powinien być uwzględniony model wzrostu ekonomicznego i ocena efektywności działania rządu rosyjskiego Ostatecznie jej przygotowanie powierzono powołanej przez rząd FR Agencji Inicjatyw Strategicznych. Por. Utwierżdieno nowyje raspriedielienija objazannostiej w prawitielstwie Rossijskoj Federacji, [w:] Federalnaja slużba po oboronnomu zakazu (Rosoboronzakaz), http://fsoz.gov.ru/press/14/687/index. html, odczyt z dn. 27.07.2012; W. Putin porucził I Szuwałowu opriedielit ekspertow dla korrektorowki strategii socjalno-ekonomiczeskogo razwitja FR, http://www.rbc.ru/rbcfreenews/20110120185055. shtml,.shtml, odczyt z dn. 27.07.2012.

3 A. Kobjakow, W. Awierjanow i W. Kuczerienko związani są z pismem „Przedsiębiorca Rosyjski”. Zbiór ponad siedemdziesięciu tekstów pod wspólnym tytułem Russkaja Doktrina reklamowany jest 
w promowanej przez Andrieja Diewjatowa Akademii Niebopolityki ${ }^{4}$, , Trzeci projekt” Kałasznikowa (Kuczerienki). a także czterotomowy „Projekt „Rosja «” wydawany w latach 2005-20105.

Prace diagnostyczno-operacyjne zawierające sugestie przeobrażeń państwa rosyjskiego w sferze mentalnej, tak na poziomie elit, jak i mas, w sferze instytucjonalno-prawnej, organizacyjnej, jak również w wymiarze geostrategicznym powstają obecnie między innymi w Instytucie EurAzES.

\section{INSTYTUT EURAZES}

Instytut utworzono w grudniu 2010 roku. Skupieni w nim analitycy, z których większość ma wykształcenie filozoficzne, ekonomiczne i politologiczne, badają i opisują procesy integracyjne i cywilizacyjne zachodzące w przestrzeni postsowieckiej, jak również warunki rozwoju Unii Eurazjatyckiej. Szczególna uwaga skierowana jest na te państwa, które są członkami lub obserwatorami Eurazjatyckiej Unii Gospodarczej. Instytut ma ambicję spełniać rolę arbitra i doradcy w kształtowaniu stosunków pomiędzy państwami wchodzącymi w ramy EurAzES jak również stosunków rosyjsko-chińskich, rosyjsko-serbskich, rosyjsko-bułgarskich, rosyjsko-greckich, rosyjsko-cypryjskich, rosyjsko-łotewskich i rosyjsko-estońskich. Poza tym jest żywo zainteresowany kształtowaniem relacji pomiędzy Rosją a Indiami, Turcją i Iranem.

Do zadań, które podejmuje Instytut, należy opracowywanie i propagowanie projektów rozwoju Eurazjatyckiej Unii Gospodarczej, opatrzonych wskazówkami co do ich realizacji. Powstają tu także, jak ogłoszono na stronie

na stronie internetowej: http://www.rusdoctrina.ru/page95505.html, odczyt z dn. 4.08.2012. W druku ukazało się zaledwie 500 egzemplarzy.

4 Podpułkownik A.P. Diewjatow pełni funkcję zastępcy dyrektora Rosyjsko-Chińskiego Instytutu Współpracy Strategicznej. Jest także sekretarzem Związku Rosyjskich Sinologów Wojskowych działającym przy Instytucie Języków Obcych Armii Czerwonej i mającym charakter klubu dyskusyjnego. Jego „doktryna”, „metodologia” i „technologia” niebopolityki (Rosji), prezentowane na licznych rosyjskich stronach internetowych, ale także w wielu publikacjach, szerokością perspektywy, erudycją, stylistyką i fantazją wizjonerską nie ustępują pracom Aleksandra Dugina. Zawiera wątki historyczne, geopolityczne, kulturologiczne, religioznawcze, etnologiczne, ezoteryczne, etyczne i inne. Zob np. Finansowo-ekonomiczeskaja wojna (strategija dla Rossiji na pieriod 2008-2015), Akademija Niebopolityki. http://www.clubvi.ru/news/2011/08/03/7//, odczyt z dn. 4.08.2012.

5 Autor zbiorowy anonimowy. Ostatni z czterech wydanych tomów wydano z ujawnieniem jednego z autorów: Jurija Szałyganowa. Zob. http://www.projectrussia29 reg.ru/, odczyt z dn. 5.08. 2012. 
internetowej Instytutu ${ }^{6}$, liczne projekty modernizacyjne ukierunkowane na współpracę polityczną i gospodarczą Rosji, Kazachstanu, Białorusi, Ukrainy, Mołdowy, Armenii i Tadżykistanu (hasło przewodnie: „Integracja przez innowację"). Zgodnie z ustawą o utworzeniu Instytutu EurAzES firmuje się on jako niezależny od wszelkich struktur politycznych, choć podkreśla swoją łączność ideową i organizacyjną między innymi ze Wspólnotą Niepodległych Państw, Eurazjatycką Unią Gospodarczą (JewrAzES), Szanghajską Organizacją Współpracy (SzOS), a także Związkiem Rosji i Białorusi (SGRiB). Do najważniejszych partnerów Instytutu należą: Naukowa Rada Ekspertów Komisji Związku Celnego Białorusi, Kazachstanu i Rosji, Instytut Politologii Państwowego Uniwersytetu Moskiewskiego im. Michaiła Łomonosowa, Instytut Organizacji Umowy o Bezpieczeństwie Zbiorowym (ODKB), Instytut Rosyjsko-Chińskiej Współpracy Strategicznej, moskiewska Akademia Problemów Geopolitycznych i Rosyjska Akademia Nauk. Instytut z powagą odnosi się do poglądów głoszonych przez Andrieja Diewjatowa, twórcy Akademii Niebopolityki, oraz innych pracowników tej wirtualnej instytucji ${ }^{7}$. Funkcję dyrektora Instytutu EurAzES pełni aktualnie Władimir Lepiechin.

Celem artykułu jest analiza dwóch pokrewnych koncepcyjnie projektów modernizacyjnych przygotowanych w IE w latach 2010-2012. Pierwszy z nich to „Modernizacja 2012” Władimira Tamaka, drugi - anonimowy „Globalny Projekt »Rosja «”. Zmierzamy do ustalenia czy treści w nich wyrażone zawierają wątki ideowe charakterystyczne dla nurtu eurazjatyzmu, co hipotetycznie można założyć, biorąc pod uwagę płaszczyznę ideową i zadania podejmowane w instytucji, gdzie projekty te zostały przygotowane. Jeśli tak, to w jaki sposób argumenty z gruntu eurazjatyckie (zakładamy, że uległy daleko idącym przetworzeniom w odniesieniu do kanonu międzywojennego) zostały przez autorów projektów wmontowane w ich postulatywną wizję zmiany przyjętych po 1993 roku kierunków rosyjskiej polityki wewnętrznej i zagranicznej. Nie mniej ważna jest ocena ważkości politycznej wybranych dwóch projektów modernizacyjnych.

${ }^{6}$ Институm Евразэс, zob. http://inst.eurasec.com/inst, odczyt z dn. 29.06.2012.

7 Pracowników Instytutu EurAzES najbardziej zapewne inspirują wykreowane w Akademii Niebopolityki przemyślenia na temat aktualnego porządku globalnego i możliwości jego przyszłych scenariuszy z uwzględnieniem pozycji, jaką zajmuje i może w przyszłości zająć Federacja Rosyjska. Zob. A.P. Djewjatow, Niebopolityka: Dla tych, którzy podejmują decyzje, Moskwa 2004; A.P. Djewjatow, О национальном достоинстве Великороссов на дальнем Востоке. Если бы я был Медведевым, http://www.apn.kz/publications/article5973.htm; A.P. Djewjatow, Niebopolitika, część 1-8, http:// alienado1.livejournal.com/136795.html, odczyt z dn. 12.07.2012. 
Czy wywarły one lub potencjalnie mogą wywrzeć jakikolwiek znaczący wpływ na decyzje polityczne obozu rządzącego?

\section{„MODERNIZACJA 2012" WŁADIMIRA TAMAKA}

Władimir Tamak jest jednym z najbardziej aktywnych i zasłużonych pracowników Instytutu EurAzES. Jest także członkiem Naukowej Rady Ekspertów Komisji Związku Celnego Białorusi, Kazachstanu i Rosji. Wchodzi w skład Rady Ekspertów Instytutu ODKB. Aktywność Instytutu w zakresie tworzenia „innowacyjnych programów" rozwoju Federacji Rosyjskiej w kontekście integracji międzyregionalnej jest w ogromnej mierze jego zasługą. W ciągu ostatnich dwóch lat dał się poznać w rosyjskim środowisku politologicznym jako twórca rozbudowanej koncepcji rozwoju Federacji Rosyjskiej. W odczuciu autora i w opinii rekomendującego ją filozofa Witalija Bielskiego jest ona „wielce oryginalna i z powodzeniem mogłaby stać się fundamentem programu politycznego prezydenta FR"•. Tamak uważa, że jego plan modernizacyjny jest aktualnie jedyną prawdziwie alternatywną propozycją pośród wielu innych tego typu ogłoszonych przed wyborami prezydenckimi 2012. To raczej życzenie twórcy niż fakt. Twierdzenie Tamaka można zresztą zweryfikować tylko w stopniu ograniczonym, gdyż autor „Modernizacji 2012” nie przedstawił jeszcze w całości jej założeń. Z planowanych pięciu tomów zawierających przemyślenia na temat stanu, perspektyw i postulowanych kierunków modernizacji sfery politycznej, gospodarczej, społecznej Federacji Rosyjskiej ukazały się dotychczas dwa: „Prawidłowości modernizacji” (2010) oraz „Koncepcje modernizacji” (2011). Wydanie pozostałych trzech tomów zatytułowanych kolejno: „Strategie modernizacji”, „,Technologie modernizacji” oraz „Projekty modernizacji” ma być zrealizowane do końca 2013 roku. Pięciotomowe dzieło Tamaka po uzupełnieniu i korekcie najprawdopodobniej ukaże się ponownie w 2015 roku pod nowym tytułem: „Metafizyka modernizacji rosyjskiej”. Niektóre jej wątki autor przedstawił w dwóch broszurach: „Cywilizacja aktywów. Koncepcja programu przekształceń cywilizacyjnych dla Prezydenta

8 Zob. W. Bielskij, O projekcie Modernizacyja 2012. Metafizyka prieobrazowanij i „kod pieriemien”, [w:] W. Tamak, Modernizacyja 2012. Kniga wtoraja: koncepcii modernizacji, Moskwa 2011, s. 6.

9 Zob. Instytut JewrAz ES, Modernizacyja 2012, http://inst.eurasec.com/dokumenty_publik/24/25/, odczyt z dn. 13.06.2012. 
FR” i „Spółki akcyjne jako sposób neutralizacji kosztów nieuczciwej prywatyzacji i czynnik integracji państw członkowskich EurAzES"10. Stawiając własne dzieło ponad innymi rosyjskimi pracami dotyczącymi reform w FR, Tamak ceni także inne prace powstające w Instytucie EurAzES, z którym jest związany, w mniejszym stopniu tworzone w instytucjach blisko z IE współpracujących o zbliżonym profilu ideowo-organizacyjnym: Instytucie Nowej Ekonomiki, kierowanym przez Siergieja Głazjewa ${ }^{11}$, Centrum Badań Społeczeństw Postindustrialnych pod kierownictwem Władisława Inoziemcewa, Instytucie Strategii Ekonomicznych, kierowanym przez Aleksandra Agiejewa, Kompanii Ekonomicznej NEOKON oraz Instytucie Projektowania Społecznego, utworzonym i kierowanym przez Walerija Fadiejewa - redaktora naczelnego tygodnika „Ekspert”.

Autor omawianego projektu podkreśla jego patriotyczny i obywatelski charakter. Przedstawia się jako opozycjonista gotowy ponieść wszelkie konsekwencje głoszenia poglądów kontrowersyjnych i świadomy obywatel kierujący się wyłącznie racją stanu i dobrem publicznym. Jego ocena działań rosyjskich i światowych elit rządzących oraz procesów charakteryzujących rosyjską scenę polityczną tak w okresie pierestrojki, jak i po 1993 roku jest niezwykle krytyczna. Program naprawczy Tamaka ${ }^{12}$ inspirowany jest jego zatroskaniem postępującym kryzysem władzy i stanem opieki socjalnej w FR, co podpowiada między innymi retoryka nacechowana irytacją i emocjami pochodnymi oraz podejmowanie wciąż na nowo wątków demaskujących mechanizmy funkcjonowania władzy rosyjskiej. Towarzyszy temu powtarzanie określeń dyskredytujących system polityczny Federacji Rosyjskiej i przyjęty w niej kurs na demokratyzację. Celem głównym, który przyświecał autorowi programu, było przygotowanie go i wręczenie Miedwiediewowi, Putinowi i zwycięzcy wyborów prezydenckich 2012 (w chwili przystąpienia do pracy nad projektem ich wynik był oficjalnie niewiadomy). Twórca traktuje go jako instrument gotowy do użycia, dopracowany pod względem pojęciowym i metodologicznym. Owa inicjatywa obywatelska

${ }^{10}$ Udostępnione pod adresem: http://inst.eurasec.com/biblioteka/5/, odczyt z dn. 6.08.2012.

11 Fundamentalna praca S. Głazjewa zawierająca koncepcję przebudowy sektora ekonomicznego zatytułowana jest Mirowoj ekonomiczeskij krizis kak process zamieszczenia dominirujuszczych technołogiczeskich układow, www.glazev.ru, odczyt z dn. 15.08.2012.

12 Biorąc pod uwagę układ formalny pracy Tamaka, dobór i sposób artykulacji tez, język wywodu, jasno określony cel operacyjny oraz oświadczenie autora, że jego projekt nie ma charakteru politycznego, informacyjnego, agitacyjnego i reklamowego, nasuwa przekonanie, iż jest wręcz przeciwnie. Zob. W. Tamak, op.cit., s. 15. 
podyktowana jest na równi pragnieniem „uratowania Rosji” z odmętów globalizacji i wybawieniem prezydenta i premiera FR od ambaras de choix wobec nadprodukcji recept na opanowanie kryzysu w FR. Jego zdaniem politycy o wykształceniu prawniczym mogą sobie $\mathrm{z}$ właściwym politycznym wyborem nie poradzić13. Ma wątpliwości, czy zdołają dostrzec jałowość koncepcji modernizacyjnych zgłaszanych przez lewicę. Wątpliwe też, by przyznali się do jałowości własnych poczynań nazywanych reformatorskimi. Podniesienie swojej pracy nad projektem do rangi gestu potencjalnego współrządzenia (choćby ograniczonego do poważnie potraktowanej konsultacji) jest oczywistą prowokacją. Jego analiza rzeczywistości rosyjskiej jednoznacznie plasuje go wśród opozycyjnie nastrojonych komentatorów polityki wewnętrznej i zagranicznej FR.

Projekt modernizacyjny Władimira Tamaka stanowi jedną z wielu istniejących dziś w FR propozycji krytycznego spojrzenia na rosyjską rzeczywistość polityczną i społeczną i jednocześnie próbą wypromowania manifestu politycznego wąskiej grupy społecznej (w tym wypadku grupy uczonych związanych z Instytutem EurAzES) o nastawieniu nacjonalistycznym. Głoszą oni podstawowe tezy eurazjatyckie (w wersji miękkiej), próbując je spopularyzować przez przesunięcie akcentu z problematyki kulturowo-prawosławnej na ekonomiczną. Podkreślają przy tym technokratyczną wartość swoich tez, w odróżnieniu od czysto teoretycznej i intelektualnej, która cechuje prawie całą produkcję eurazjatycką i neoeurazjatycką, tym samym utrzymując ją na marginesie zainteresowania społecznego.

Zdaniem Tamaka wszystkie plany reform zgłaszane przez centrum i lewicę w okresie 2010-2012 w FR miały charakter jedynie teoretyczny i propagandowy. Planami i projektami rzeczywiście można je uznać tylko w sensie largo, nie były bowiem dopracowane pod względem operacyjnym, nie były choćby w małym stopniu „technokratyczne”. Tamak poważa tylko te, które spełniają formalne kryteria projektu, zawierają praktyczne wskazówki odnośnie do zmian w sferze

${ }^{13}$ Wydaje się, że uwaga o wąskim wykształceniu prezydenta i premiera FR nie ma tu na celu dyskredytacji głowy państwa i szefa rządu, lecz koresponduje z wnioskiem Tamaka, by zastosować swoistą selekcję osób sprawujących władzę pod kątem ich poglądów prodemokratycznych i patriotycznych oraz zdolności do skutecznego działania. O jej posiadaniu świadczyć ma m. in. gotowość do niezwłocznej realizacji projektów modernizacyjnych, w szczególności tych, które piszą analitycy wywodzący się z szeregów kadry analitycznej Instytutu EurAzES. Tamak swoje nadzieje polityczne uzależnia od tego, czy „spółka Putin i Miedwiediew” utrzyma się przy władzy „obojętnie w jakiej konfiguracji”, a także od tego, czy jego manipulacyjne wezwanie obu polityków do uwierzytelnienia odniesie zamierzony skutek. Zob. W. Tamak, op.cit., s. 15, 74. 
ekonomii i życia społecznego i są osadzone w ramach wyraźnie nakreślonej ideologii „narodowej”. Podkreśla, że jej eksplikacja w niczym nie powinna przypominać „filozoficznej gumy do żucia” produkowanej i spożywanej przez „patriotów” rosyjskich. Zwykły technokratyzm uważa za niewystarczający ze względu na brak w nim elementu etycznego. Jeśli ma rodowód naukowy, widzi go przydatnym dla dowartościowania programów reformatorskich. Jednakże technokratyczne programy reform są dla niego w każdym przypadku instrukcją bez mocy ideowej. Technokraci mogą dostarczać właściwych wniosków, rad i pomysłów, ale nie są zdolni porwać masy i nie są skłonni podążyć za charyzmatycznym liderem, który - jak uważają analitycy z kręgu IE - musi w końcu się wyłonić. Tamak szuka nowej formuły i znajduje ją w pojęciu nowej technokracji. Nowi technokraci - jak objaśnia - to naukowcy nie tylko w dziedzinie nauk ścisłych, społecznych i ekonomicznych, lecz także humanistycznych, ludzie „z duszą," moralni, odpowiednio zmotywowani, potrafiący przekonać Rosjan do swoich racji i zmobilizować do działania. Swój projekt „Modernizacja 2012” uważa za najważniejszy, najbardziej rzetelny i obiecujący przykład nowego podejścia technokratycznego. Technokratyczne i naukowe opakowanie nacjonalizmu własnego i współpracowników w macierzystej i zaprzyjaźnionych strukturach jest pomysłem marketingowym. Nie na tyle jednak atrakcyjnym, by przezwyciężyć sprzeciw biurokratyczny wobec projektów „przebudowy Rosji” alternatywnych wobec planów rządowych, nie dość nowatorskim, by zyskać uwagę dla treści „Notatek do Najwyższej Instancji FR”, zawierających wnioski i postulaty formułowane w ramach organizowanych w IE cyklicznie od marca 2011 roku warsztatów strategicznych.

Jedna z dwóch zasadniczych tez o powszechnej oligarchizacji systemów politycznych może być podstawą sądu, że dla Tamaka demokracja istnieje tylko w postaci typu idealnego. $Z$ drugiej strony postuluje on rozwój samorządowości i wyprowadzenie właściwej, niepozorowanej opozycji rosyjskiej z „podziemia” lub „półpodziemia” do organów władzy. Byłoby to istotną korektą „suwerennej demokracji” zbliżającą ją do modelu idealnego. Tamak, przyjmując, jak większość nacjonalistów rosyjskich, że Federacja Rosyjska powinna iść własną (trzecią) drogą, nie neguje Putinowskiej idei „suwerennej demokracji”. Uważa jednak, że ani ta, ani postulowana przez niego poprawiona (choć nie według wzoru zachodniego i nie idealna) demokracja rosyjska nie może być uważana za ewenement w skali oligarchicznego pseudodemokratycznego świata. Jest i pozostanie demokracją tylko z nazwy.

Rozprawa o modernizacji Federacji Rosyjskiej, bo tak chyba należy nazwać pięciotomowe dzieło Tamaka, niezupełnie w zgodzie $\mathrm{z}$ analitycznymi zamiarami 
badacza jest subiektywną, dość pobieżną i w dużej mierze uproszczoną wizją współczesnej politycznej rzeczywistości rosyjskiej, do której dołączono „uzdrowicielską" doktrynę. Właśnie doktryna - naukowa w formie i nacjonalistyczna w treści - jest głównym przedmiotem obróbki techniczno-analitycznej Tamaka, program ma z niej wynikać ${ }^{14}$. Szczegółowa ocena sytuacji politycznej i społecznej FR uzasadnia stanowczy postulat zreformowania bytu rosyjskiego na wszystkich poziomach - od powszechnie wyznawanego systemu wartości do priorytetów w polityce międzynarodowej. Kierunek reform i ich sukces zależy - zdaniem Tamaka - od wyboru doktryny przewodniej. Znamienne jest przekonanie o tym, że głównym motorem rozwoju historycznego państw i narodów są idee, a nie instytucje i ludzie (ideoprawstwo). To jest charakterystyczne tak dla klasycznej, jak i współczesnych wersji eurazjatyzmu.

Całościowej wieloaspektowej analizy koncepcji modernizacyjnej Tamaka można się podjąć dopiero, gdy autor ją opublikuje. W tej chwili mamy tylko jej zapowiedź i mniej lub bardziej dopracowane fragmenty bazowe. Jednym z nich jest ogólna ocena potencjału reformatorskiego wśród przedstawicieli wiodących, ciekawie scharakteryzowanych grup politycznych oraz niepełny obraz rosyjskiego systemu politycznego wielokrotnie nazwanego oligarchicznym.

\section{OLIGARCHIA ŚWIATOWA. PORZĄDEK ŚWIATOWY}

Władimir Tamak jako teoretyk polityki nie neguje sensowności rozróżniania reżimów politycznych na demokratyczne i autorytarne. Dla niego podział ten ma jednak wartość o tyle, o ile ma wartość wiedza zawarta w podręcznikach z zakresu systemów politycznych. Nie chodzi o przypomnienie oczywistego faktu, że demokracja w typie idealnym w rzeczywistości politycznej nie występuje. Mówienie o różnych formach demokracji jest, jego zdaniem, rozwijaniem mitu o demokracji. W jego przekonaniu na całym świecie, od USA, przez Koreę Północną, WB, Iran, Federację Rosyjską aż po Chiny, ukonstytuowały się rządy „niewielu” powiązanych z określonymi niewielkimi grupami, klanami i rodzinami. Oprócz nielicznych przypadków tyranii, które „stopniowo odchodzą w przeszłośćc ${ }^{15}$, we wszystkich regionach świata dominują rządy oligarchów. Zrost władzy politycznej z władzą ekonomiczną jest aktualnie jednym z wio-

\footnotetext{
14 Zob. W. Tamak, op.cit., s. 61.

15 Zob. ibidem, s. 39.
} 
dących trendów światowych. Ulegają mu zarówno instytucje narodowe, jak i ponadnarodowe. Różnica między porządkami oligarchicznymi w regionach i poszczególnych państwach polega na przewadze w nich bądź sił wojskowych i służb specjalnych (np.w USA), klanowo-urzędniczych (np. w Korei Płn.) bądź wojskowo-urzędniczych związanych z Kościołami (np. oligarchia teokratyczna w Iranie). Oligarchia rosyjska, podobnie jak chińska, ma charakter administracyjno-finansowy. Od lat siedemdziesiątych w Rosji rządzą służby specjalne $\mathrm{w}$ porozumieniu $\mathrm{z}$ bezpośrednimi dysponentami surowców naturalnych.

Tezę o hegemonii „oligarchii światowej” poprzedza wyjaśnienie terminologiczne, z którego wynika, iż należy ją definiować nie poprzez opis struktury podmiotu określanego jako „oligarchia” (tak światowa, jak i w ramach poszczególnych regionów i państw), lecz drogą analizy funkcjonalnej. Ustalenie, kto jest oligarchą ,globalnym", stanowi dla Tamaka problem poboczny. Na początek wystarczy uznać, iż jest to kluczowego znaczenia kolektyw, który kolektywem pozostanie, bo przecież trudno (nie tylko z powodów proceduralnych) wyobrazić sobie wybory np. Prezydenta Planety Ziemia. Najważniejsze jest zrozumienie sposobu działania „ponadpaństwowych podmiotów oligarchicznych” i określenie, z jakim typem rządzenia i kontroli procesami politycznymi w skali świata mamy do czynienia. Jakie specjalnie upełnomocnione organy ponadnarodowe należą do głównych decydentów? W szczególności należy ustalić, w jaki sposób i za pomocą jakich instrumentów działa rząd światowy. Skoro oligarchia jest dziś w zasadzie jedynym (prócz reliktowych postaci tyranii) realnie występującym typem reżimu politycznego, umieszczanie go na linii continuum w stosunku do idealnych postaci demokracji i nie-demokracji może mieć wartość jedynie teoretyczną. Dla Tamaka zaś ważna jest przede wszystkim rzeczywistość polityczna, a najbardziej możliwość jej praktycznego kształtowania. Z pobłażliwością odnosi się do „konspirologii” uprawianej przez Pata Robertson $\mathrm{a}^{16} \mathrm{i}$ agenta brytyjskich służb specjalnych Johna Colemana ${ }^{17}$. W takim samym stopniu dystansuje się od teorii spiskowych o działalności „wewnętrznego kręgu”"18, światowej Lichwy z Williamsburga ${ }^{19} \mathrm{i}$ Komitetu 300 , choć uważa, że twórcy tych „naiwnych” teorii trafnie wskazali najbardziej wpływowych w skali globu oligarchów. Są nimi mię-

16 Zob. P. Robertson, The New World Order, Dallas, Texas, 1991.

17 Zob. J. Coleman, Conspirators Hierarchy: The Story of the Committee of 300, Carson City 2005.

18 Zob. T. Marrs, Cirle of Intrique. The Hidden Inner Circle of the Global Illuminati Conspiracy, Texas 1995.

19 W 1983 roku Światowa Lichwa zaplanowała w Williamsburgu strategię przygotowania USA na całkowitą dezintegrację systemu bankowego tego kraju. Zob. H. Pająk, Komitet 300 „Sanhedrynem” 
dzy innymi Zbigniew Brzeziński, Henry Kissinger, a także Paul Dundes Wolfowitz - wiceminister obrony USA, prezes Banku Światowego w latach 2005-2007 i Jacques Attali - prezes organizacji non profit Planet Finance. Jako zdeklarowany antyamerykanista i antyglobalista odrzuca wizję porządku międzynarodowego ogłoszoną przez Brzezińskiego. Najbardziej bliska mu jest „,naukowa”, „oparta na faktach”, pozbawiona „dziennikarskiej powierzchowności” i „prawidłowo rozstawiająca akcenty" analiza nowego porządku światowego sporządzona przez rosyjskich technokratów - socjologa Siergieja Głazjewa, politologa Aleksandra Agiejewa i ekonomisty Michaiła Chazina. Centralne jest w niej przekonanie, że architektura tego porządku została stworzona w Waszyngtonie i jej stan jest nieustannie stamtąd kontrolowany. UE z rządem europejskim, NATO, ONZ, WTO, G7, Rada Dyrektorów „Gazpromu”, Bank Światowy i inne banki - bądź powiązane z rodzinami Rockefellerów i Rothschildów, bądź banki rosyjskie obywające się bez związków z zachodnimi przedsiębiorcami i filantropami ( $w$ tym zarejestrowany na Cyprze bank „Rumianek” należący do Borysa Fiodorowa - byłego ministra finansów FR) - podporządkowane są globalistycznym interesom USA. Po 11 września 2001 roku interesy te zostały staranniej niż do tej pory zabezpieczone, wskutek czego wzrosła rola organizacji między- i ponadnarodowych, zaś sądownictwo międzynarodowe stało się ważniejsze niż państwowe. Wzrosła także możliwość ingerencji w politykę wewnętrzną państw pod pretekstem m.in. zabezpieczenia pokoju na świecie, zniesiono większość barier dla wywiadu amerykańskiego, co uzasadnia się koniecznością zwalczania terroryzmu. Rządy „Syndykatu”20 przy udziale amerykańskich służb specjalnych i Pentagonu wprawdzie próbują zmusić wszystkie państwa do włączania się w mechanizmy globalizacji, ale nie wszystkie poddają się tej presji. Federacja Rosyjska otwiera listę tych, które wykazują wobec niej skuteczny opór. Wśród innych, które nie przyjmują bezkrytycznie zasad nowej globalizacji, kultu Złotego Cielca ${ }^{21}$ i amerykańskiego mitu o wzrastaniu społeczeństwa informacyjnego i które nie dały się jeszcze całkowicie omamić wątpliwymi pożytkami „netokracji” ${ }^{22}$, Tamak wymienia: Kazachstan, Azerbejdżan,

Rządu Światowego, http://ligaswiata.blogspot.com/2012/02/komitet-300-illuminati-rzad-swiatowy. html, odczyt z dn. 8.07.2012.

20 Zob. N. Hagger. The Syndicate. The Story of the Coming World Government, Alresford 2004, s. 37. Tamak kilkukrotnie powołuje się na poglądy angielskiego historyka i filozofa.

21 Zob. W. Tamak, op.cit., s. 42.

22 Do szczególnie niebezpiecznych efektów „netokracji” Tamak zalicza niekontrolowany przepływ informacji. Społeczeństwa „netokratyczne” są mało refleksyjne, zdezorientowane, zdemoralizowane, co jest bezpośrednim skutkiem przeniesienia różnorakich form aktywności na poziom wirtualny, gdzie wszelkich działania, w tym działania i decyzje polityczne, mają charakter iluzoryczny i, przy- 
Turkmenistan, Indie, Wietnam, Chiny (o ile tajwańskie i chińskie banki wycofają się z powiązań z bankami londyńskimi i grupą finansowo-bankową HSBC i pod warunkiem, że Exxon Mobil przestanie kontrolować złoża ropy w Mandżurii) ${ }^{23}$, Wielką Brytanię, Arabię Saudyjską, Iran, Indonezję, Australię, Brazylię, Boliwię, Wenezuelę i Norwegię 24 . Kryterium doboru podmiotów na tej liście w dużej mierze powiela koncepcję odbudowy układu dwubiegunowego i strategicznej równowagi Aleksandra Dugina ${ }^{25}$, którego twórczość Tamak ceni na równi z pracami angielskiego historyka, filozofa i poety Nicholasa Haggera oraz analityków z Akademii Problemów Geopolitycznych i z Akademii Niebopolityki. Dugin wyznacza sojuszników w walce z „atlantyzmem” wedle kryterium geopolitycznego (stąd u niego Wielka Brytania wraz z USA należy do „Cywilizacji Morza”), zaś Tamak bardziej kieruje się kryterium polityczno-ekonomicznym ${ }^{26}$. Ich intencja spotyka się na poziomie operacyjnym: przywrócić porządek dwubiegunowy, przeciwstawiając „sile zawłaszczającej zasoby światowe” za pomocą wojsk NATO sojusz państw sprzymierzonych z Federacją Rosyjską i tym samym odzyskać pozycję i autorytet Rosji jako centrum przestrzeni eurazjatyckiej. Powrót do straconej w połowie lat osiemdziesiątych XX wieku roli najważniejszego obok USA gracza w polityce światowej jest dla Tamaka zadaniem pierwszorzędnym. Z racji tego, że „światowa grupa wpływu powinna mieć dwie, a nie trzy ręce”, należy dążyć

najmniej w części, zastępczy. Krytyka „netokracji” nie jest u Tamaka równoznaczna z odrzuceniem Internetu jako zdobyczy technicznej. Szczególnie wtedy, gdy służy rozpowszechnianiu treści opozycyjnych, jak w przypadku aktywności sieciowej znanego adwokata rosyjskiego Aleksandra Nawalnego.

${ }^{23}$ Znaczenie Chin dla rozwoju rynku globalnego nie pozwala zaliczyć ich bezwarunkowo do bloku państw opornych wobec globalizacji. Stąd w koncepcji Tamaka Chiny - zapewne z powodu strategicznego sąsiedztwa - raz występują jako ważny podmiot przestrzeni eurazjatyckiej, to znów jako „siła robocza trzeciej globalizacji” (pierwszą był radziecki projekt komunistyczny, drugą - wszystkie próby jednoczenia Europy). Zob. W. Tamak, op.cit., s. 47.

24 Ibidem, s. 44.

25 Zdaniem A. Dugina unifikacji świata może położyć kres jedynie utworzenie wielopodmiotowej struktury, której centrum będzie Rosja (ze względu na status heartlandu Eurazji oraz potencjał strategiczny). Przyłączyć do niej należy państwa oderwane po rozpadzie ZSRR, niektóre państwa Bliskiego Wschodu i Maghrebu, Iran, Indie, Chiny i państwa Dalekiego Wschodu położone w strefie Pacyfiku. Zob. A. Dugin, Nasz put'Strategiczeskije perspektiwy razwitja Rossiji w XXI wiekie, Moskwa 1999, s. 95.

${ }^{26}$ Niezależność w porządku światowym (konstytuowanym przede wszystkim przez Międzynarodowy Fundusz Walutowy, Bank Światowy i inne banki, które wyrosły na prywatyzacji aktywów ZSRR) w szczególności sprowadza się tu do swobodnego rozporządzania rodzimymi zasobami surowców energetycznych, kamieni szlachetnych, rud metali i opium jako waluty rezerwowej. Zob. W. Tamak, op.cit., s. 45. 
do tego, by wszechstronny rozwój i ekspansja Federacji Rosyjskiej przewyższyły potencjał i dążenia Imperium Środka. Jeśli modernizacja FR w krótkim czasie nie nastąpi, w 2019 roku Chiny zdystansują USA i staną się jedynym mocarstwem światowym. Wprawdzie nie na długo, bo już okresie 2022-2027 - jak twierdzi Tamak, powołując się na prognozy analityków z Akademii Niebopolityki - na pozycję supermocarstwa mogą wybić się państwa islamskie zgrupowane bądź wokół Iranu (projekt „Islamska Umma”), bądź wyłonią lidera spośród państw sunnickich. Wyścig mocarstw mogą też wygrać dynamicznie rozwijające się Indie, państwa Ameryki Łacińskiej lub Japonia. Europa - zdaniem rosyjskiego geostratega - pierwszoplanowej pozycji nie zajmie. Jej szanse zostały zaprzepaszczone przez twórców Unii Europejskiej, która jest tworem sztucznym, ekonomicznie i politycznie niewydolnym. Tamak przyznaje rację koledze z Rady Instytutu EurAzES Walerijowi Munirowowi, który przyczynę spadku światowej roli Europy upatruje w błędnym wyborze płaszczyzny jej jednoczenia. Obaj uważają, że polityczna i ekonomiczna siła Europy potencjalnie istnieje w znajdujących się tu dziewięciu monarchiach i w Watykanie. Europa mogłaby awansować do grupy supermocarstw tylko wtedy, gdyby monarchie europejskie zgodnie uznały roszczenia Watykanu, zerwały związki z „Bilderbergiem” i innymi organizacjami ponadnarodowymi o charakterze klubu, uniezależniając się tym samym od „światowego kapitału” i NATO27.

Według Tamaka nawarstwiające się problemy w polityce wewnętrznej Federacji Rosyjskiej ${ }^{28}$ i jej działalność na forum międzynarodowym ${ }^{29}$ wymagają natychmiastowej akcji zaradczej. Wielokrotnie twierdzi, że bezpieczeństwo wewnętrzne FR może jej przywrócić jedynie poważnie potraktowany przez prezydenta FR Putina nowy projekt globalny ${ }^{30}$.

27 Ibidem, s. 52-53.

28 Do najważniejszych Tamak zalicza niedocenianie przez elitę rządzącą znaczenia interesów poszczególnych narodów RF, rozczłonkowanie tej elity, brak efektywnie wdrażanej doktryny bezpieczeństwa narodowego, brak koncepcji polityki wewnętrznej i masowe wyjazdy wykształconych Rosjan za granicę.

${ }^{29}$ Uczestnictwo FR w Radzie Bezpieczeństwa ONZ, w G8, czterostronnej Komisji do spraw Bliskiego Wschodu, sześciostronnej Komisji do spraw Korei Północnej nie musi świadczyć o jej zaangażowaniu sprawy międzynarodowe. Analitycy Instytutu EurA zES uważają, że ma ono raczej charakter fasadowy.

30 Do prac na temat strategii światowej i rosyjskiej opracowanych w Instytucie EurAz ES należy książka S. Głazjewa, Genocyd, Rossija i nowyj Mirowoj porjadok, Moskwa 1997. Na ten temat również zob. W. Munirow, Mobilizacyja smysłow (wystąpienie na konferencji Nowyje ugrozy nacyonalnoj biezopastnosti Rossijskoj Federacji, zorganizowanej w Rosyjskiej Akademii Służby Państwu 2.10.2008 roku). 


\section{OLIGARCHIA ROSYJSKA. PORZĄDEK ROSYJSKI}

Podczas gdy porządek światowy, zgodnie z liberalno-demokratycznymi i globalistycznymi założeniami jego organizatorów, szybko zmierza do jednobiegunowości, porządek wewnętrzny FR jest dwubiegunowy. Na pierwszym, „elitarnym” (cudzysłów za Tamakiem) biegunie są urzędnicy państwowi związani z potentatami finansowymi i sami zawiadujący znacznym kapitałem nabytym bądź w ZSRR z klucza KPSS, bądź podczas pierwszych lat prywatyzacji w FR. Na drugim biegunie znajdują się przeciwnicy porządku oligarchicznego i dalszej liberalizacji rynku rosyjskiego. To „antyoligarchia” złożona z osób, które w okresie "gajdaryzacji” nie zdołały zająć miejsca w strukturach władzy lub/i biznesu. Federacją Rosyjską zatem rządzi elita oligarchiczna, tworząc porządek oligarchiczny, reszta społeczeństwa rosyjskiego to konsumenci skutków tego porządku. Utrzymanie porządku oligarchicznego jest dla elity rządzącej równoznaczne z utrzymaniem i pomnażaniem zysku w postaci dostępu do władzy i pieniędzy. Tamak podkreśla, że zachowanie, a nie zmiana politycznego status quo jest głównym celem oligarchicznej elity władzy i związanych z nimi właścicieli wielkich korporacji. Słabo skrywana koncentracja na tym właśnie celu dyskredytuje ją i delegitymizuje. Tamak wyraża nadzieję, że antyolicharchiczna część społeczeństwa rosyjskiego doprowadzi do katastrofy narodowej - odsunięcia od władzy zwolenników demokracji i choćby tylko umiarkowanego i wybiórczego liberalizmu (z wyłączeniem liberałów typu sacharowskiego, którzy widzą FR w równorzędnym „braterskim” układzie z USA, a nie w relacji podporządkowania interesom USA). Tym samym wzmocniłaby się tendencja tradycjonalistyczna. Chyba że w łonie obozu kremlowskiego zrodzi się „narodowa” (rosyjska) wersja liberalizmu blokująca dalszą „natoizację” i „dolaryzację” FR, której ważnym składnikiem będzie program opieki społecznej ${ }^{31}$. Nie zagłębiając się $\mathrm{w}$ analizę odmian rosyjskiego tradycjonalizmu, Tamak prawdopodobnie zakłada, że propagowany przez niego tradycjonalizm neoeurazjatycki jest bezkonkurencyjny dla innych jego wariantów. Powrót do tradycji powinien być - jego zdaniem - jednoznaczny, nieodwołalny, obejmujący wszystkie sfery funkcjonowania państwa, a także politykę zagraniczną. Jakkolwiek brzmi to paradoksalnie, powinien mieć charakter innowacyjny, a nie radykalnie konserwatywny. $Z$ takich właśnie pozycji tradycjonalistycznych Tamak jednakowo

31 W. Tamak, op.cit., s. 92. 
odżegnuje się od „liberalnego konserwatyzmu” Jedinoj Rossiji i Sprawiedliwoj Rosiji ${ }^{32}$ (który niekiedy nazywa postsowieckim konserwatyzmem „nowych Rosjan" lub noworosyjskim korporacyjnym konserwatyzmem klasy rządzącej), lewicowego „konserwatyzmu” właściwego Komunistycznej Partii Rosyjskiej Federacji (w tym konserwatyzmu stalinowców) i „patriotycznego konserwatyzmu" głoszonego w Liberalno-Demokratycznej Partii Rosji. Obce są mu także, co zrozumiałe, wszystkie typy konserwatyzmu o proweniencji zachodniej, zwłaszcza neokonserwatyzm republikanów amerykańskich i niemieckiej chadecji. Tamak rozumie jednak, że pomysłowość i nastawienie ideowe bez pragmatyzmu i public relations $\mathrm{w}$ większości są bezpłodne. Wie, że nim antyoligarchia zdobędzie się na organizację buntu, który nie ograniczy się do czczej demonstracji niezadowolenia, lecz skutecznie wymusi na Putinie szereg posunięć reformatorskich, szanse na realizację jego i kolegów z IE „jedynie słusznego” programu reform zależą od liberalnego - choćby tylko deklaratywnie - obozu prezydenckiego. Ostatecznie tylko on zdołał formalnie zgłosić (nota bene przed wyborami 2012) początek dalszych reform. „Konserwatyści” i „patrioci” wprawdzie również głoszą konieczność przemian społecznych i politycznych, ale nie mają mocy decyzyjnej. Z tego zapewne powodu Tamaka krytyka „neofaszystowskich” i „ludożerczych” 3 rządów oligarchii rosyjskiej zawiera ostatecznie pozytywną ocenę osiągnięć obozu rządzącego w dziedzinie ekonomii i nauki. Chwali żywego w nim ducha postępu. Jednak, jego zdaniem, ani sukcesy ekonomiczne, ani klimat reformatorski nie czynią z oligarchicznej elity władzy reformatorów z prawdziwego zdarzenia. Ani Miedwiediew, ani Michaił Prochorow jako właściciel „Norylskiego Niklu” nie mogą firmować poważnego projektu przebudowy państwa rosyjskiego. Symbolem czasu reform i zreformowanej Rosji może stać się jedynie Putin, jeżeli z lidera „liberalnego” (z zapleczem przekonań „konserwatywnych”) przeistoczy się w lidera „narodowego”.

O ile samo przekonanie o konieczności modernizacji w jakimś stopniu łączy analityków Instytutu EurAzES i obóz rządzący, obrany przez jednych i drugich kierunek zmian oraz wizja sytuacji państwa i społeczeństwa zreformowanego są całkowicie różne. Polityka wewnętrzna i zagraniczna FR kreowana jest adekwat-

${ }^{32}$ Liberalizm i konserwatyzm jako dwa przeciwstawne kierunki ideowe wyraża - zdaniem Tamaka - herb FR. Zwraca przy tym uwagę, że inne interpretacje symbolu orła dwugłowego z powodzeniem mogą potwierdzać jego przekonanie wniosku o schizofrenii rosyjskiego bytu politycznego i dwulicowości władzy rosyjskiej. Zob. ibidem, s. 122.

33 Ibidem, s. 95-96. 
nie do dominującego wśród członków Zjednoczonej Rosji przekonania, że państwo to w chwili obecnej jest aktorem mało konkurencyjnym. Budowanie konkurencyjności decydenci polityczni uzależniają od zaawansowania liberalizacji rynku w warunkach kontrolowanej kooperacji z państwami zachodnimi. Zespół uczonych Instytutu EurAzES uważa, że pogląd o niskiej konkurencyjności FR na rynku globalnym jest destrukcyjny. Tamak odrzuca zarówno koncepcję integracji organicznej, której hołdował Miedwiediew jako prezydent FR, jak i realistyczną koncepcję integracji z Zachodem, którą przyjęli Anatolij Czubajs i Prochorow. Reprezentuje nietypową wśród analityków i działaczy IE postawę radykalnie antyzachodnią. Wiara demokratów u władzy w integrację organiczną (Tamak dopatruje się w niej korzeni romantycznych) jest tożsama z przekonaniem, że Europa w dobie globalizacji nie zamknie się na współpracę z FR, stale będzie szukać czynników połączenia, a nie separacji. Z tego punktu widzenia istotne stają się dla nich wszelkie działania budujące klimat zaufania w stosunkach Rosja-Zachód. Gotowość do kompromisów (m.in. w kwestii przesyłu paliw) traktowano jako cenę „przyjęcia” FR do Europy i pozyskania kapitału europejskiego na potrzeby gospodarki rosyjskiej. Ci spośród zwolenników liberalizmu i demokracji, którzy w Europie obserwują raczej niechęć wobec FR i poczucie cywilizacyjnej odrębności (Europa to nie Eurazja), nie liczą na „organiczne” zjednoczenie. Uważają, że liberalizacja i demokratyzacja FR musi odbyć się bez pomocy Europy i niezależnie od jej nastawienia do tej sprawy. Zamiast wdzięczyć się do Europy i przystawać na jej często niekorzystne warunki, należy zdemokratyzować porządek rosyjski choćby „na siłę”34. Potem można przyłączyć FR do Europy, nie czekając, aż ona ją przyłączy. Zdaniem Tamaka duża grupa osób związanych z elitą władzy w ogóle nie rozważa strategii liberalizacji i demokratyzacji bytu rosyjskiego i jej - w związku z tym - miejsca względem Europy. Nie wierzy w możliwość przeprowadzenia działań z jakąkolwiek koncepcją, która nie byłaby tą, którą przyjął prezydent i premier FR. Tym samym odrzuca sensowność podejmowania prób zburzenia porządku oligarchicznego (tym bardziej jeśli, co wcześniej zostało powiedziane, tworzy ten porządek we własnym interesie). W tym przekonaniu łączy się z ogromną częścią społeczeństwa rosyjskiego, które dalekie jest od określania się w kategoriach demokracji i liberalizmu.

Jedną z najbardziej symptomatycznych cech aktualnego porządku rosyjskiego jest - według Tamaka - pozorowany pluralizm. W polu oglądu rosyj-

34 Ibidem, s. 110. 
skiego badacza znalazły się najważniejsze obecnie w FR nurty polityczne. Ich klasyfikacja jest swoista. Zrezygnowano z klasycznego w publicystyce i nauce rosyjskiej podziału na demokratyczną prawicę, lewicę nacjonalistyczną i komunistyczną (tzw. obóz patriotów) oraz centrum, w którym znajdują się partie władzy ${ }^{35}$. Zamiast tego zastosowano oparte na kryterium ideowym rozróżnienie na ugrupowania „liberalne”, „konserwatywne”, „narodowo-patriotyczne”, „socjalistyczne” i „lewicowe niesocjalistyczne”. Przywołany tu za Tamakiem cudzysłów oznacza wyrażone w ten sposób przekonanie autora o braku związku nazw i programów wszystkich wymienionych formacji z sugerowanym nazwą kierunkiem ideowym. W tym sensie wszystkie one są fasadowe. Tamaka interesuje, $\mathrm{w}$ jakim stopniu są w nich obecne realne, a nie tylko deklarowane dążenia modernizacyjne. Odpowiedzi na to pytanie dostarcza przeprowadzona przez niego analiza porównawcza treści programowych właściwych wyodrębnionym czterem ugrupowaniom. Badanie wykazało, że tak jak programy badanych ugrupowań nie różnią się zasadniczo między sobą, tak i pomysły modernizacyjne ogłaszane przez każdą z nich są podobne. Wzięte pod uwagę wszystkie partie parlamentarne, ich programy oraz najbardziej reprezentatywne na rosyjskiej scenie politycznej i medialnej pomysły modernizacyjne stanowią, co zostało zobrazowane w stosownych zestawieniach, wobec siebie alternatywę pozorną. Występujące w części przypadków wrażenie opozycyjności to rzekomo efekt specjalnych zabiegów. Badanie Tamaka prowadzi do wniosku, że rosyjski system oligarchiczny cechuje pozorowany pluralizm utrzymywany i kontrolowany przez elitę rządzącą w celu legitymizowania jej władzy. Analiza porównawcza deklaracji programowych rosyjskich „liberałów” 36 i „konserwatystów” w odniesieniu do praktycznych działań jednych i drugich dowodzi zasadniczej rozbieżności między stanem normatywnym i empirycznym.

Wartości programowe, które Tamak uznał za kluczowe w ogólnie pojętym programie „liberałów” - wolność, demokracja, wolny rynek i prawa człowieka - nie są alternatywne, lecz komplementarne dla wartości - jego zdaniem - głów-

35 Zob. R. Bäcker, Rosyjskie myślenie polityczne za czasów prezydenta Putina, Toruń 2007, s. 42.

${ }^{36}$ Treść, która w badaniu uznana została za program liberalny, ustalono na podstawie analizy dokumentów programowych ugrupowań poprzedzających utworzenie Zjednoczonej Rosji: Partii Rosyjskiej Jedności i Zgody, partii „Nasz Dom-Rosja” oraz partii „Jedność”. Zjednoczona Rosja, jako kompilacja tendencji liberalnych i konserwatywnych, ze względu na swą hybrydowość znalazła się tu poza polem badania rosyjskiego liberalizmu. Ciekawe, że program „konserwatystów” rosyjskich został scharakteryzowany nie na podstawie badania programów rosyjskich ugrupowań konserwatywnych, lecz na podstawie Manifestu oświeconego konserwatyzmu.Zob. W. Tamak, op.cit., s. 142-144. 
nych w programach „konserwatystów” - porządku w państwie, sprawiedliwości, równości i prawa do pracy. Jedynie rozumienie stabilności państwa i bezpieczeństwa socjalnego jest elementem różnicującym dążenia „liberalne” i „konserwatywne”. „Konserwatyści” uważają, że źródłem tego bezpieczeństwa powinno pozostać państwo rosyjskie, „liberałowie” wiążą je z możliwością swobodnego rozwoju jednostek i konkurowania na rynku. W myśli „liberalnej” stabilność państwa wiąże się z jego ustawicznym rozwojem, w szczególności ekonomicznym, dla „konserwatystów” - z gwarantowanym przez państwo minimum socjalnym i zachowaniem tradycyjnego sposobu myślenia.

\section{"GLOBALNY PROJEKT »ROSJA«"}

W duchu nowatorskiego technokratyzmu neoeurazjatyckiego utrzymany jest także anonimowy dokument podpisany 15 maja 2011 roku na jednym z zebrań IE, zatytułowany „Rosja: obraz przyszłości. (Globalny projekt »Rosja«)”. W książce „Modernizacja 2012” jest on przytoczony w całości jako wzór pracy konceptualnej, która może i powinna doprowadzić do stopniowych przeobrażeń na poziomie świadomości masowej, na poziomie funkcjonowania elity rządzącej, w ekonomii i polityce społecznej. Trudno stwierdzić stopień uczestnictwa Tamaka w formułowaniu „Globalnego projektu «Rosja», w każdym razie większość zawartych w nim tez jest zgodna z poglądami autora projektu „Modernizacja 2012”. Podporządkowane są czterem zasadniczym w myśli eurazjatyckiej założeniom: o samoistności i samowystarczalności cywilizacji eurazjatyckiej; o konieczności wyłączenia Rosji (obecnie jak największej ilości państw obszaru byłego ZSRR) z procesów globalizacyjnych, co jest odpryskiem skrajnego antyeuropocentryzmu; o konieczności ochrony wartości narodowych rozumianych jako tradycyjny dorobek społeczeństwa wieloetnicznego skumulowany w kulturze rosyjskiej; o misjonistycznej powinności Rosji w odniesieniu do Zachodu, który zagubił się w swych dążeniach.

Klasyczni eurazjaci, a wśród nich zwłaszcza Nikołaj Trubieckoj, przy pełnym urazy dystansie do europejskiej tendencji do oceny poszczególnych regionów i cywilizacji w kategoriach postępowości i zacofania, podziwiali dorobek cywilizacyjny Europy. W okresie międzywojennym, gdy ukazywały się pierwsze prace eurazjatów, potęga USA, Japonii i Chin była sprawą przyszłości, w dodatku intelektualistom i uczonym nie uchodziła - zwłaszcza w ramach formacji z założenia niepolitycznej - kreacja czarno-białej wizji świata i nachalne agitatorstwo. Doku- 
ment IE ma charakter wyraźnie propagandowy. Europa jest w nim przedstawiona jako państwo dążące do unicestwienia FR jako bytu politycznego, prawnego, narodowego i kulturowego oraz przejęcia jej bogactw naturalnych i potencjału demograficznego. O ile Tamak w pracy „Modernizacja 2012” demaskuje zależność państwa rosyjskiego i jego elit od sterowanego z Waszyngtonu układu oligarchicznego, w którym UE zajmuje ważne miejsce, autorzy „Globalnego projektu "Rosja «" koncentrują się na zależności FR od Strassburga, Londynu i Brukseli. W przeciwieństwie do Tamaka podkreślają, że FR ciągle jeszcze ma wybór. Jeśli pójdzie drogą reform „liberalnych” i kompromisów europejsko-amerykańskich zostanie wchłonięta przez Europę. Z czasem stanie się terenem jej starcia z Chinami. Jeśli wybierze drogę rozwoju niezależnego od trendów światowych, umocni się jako centrum cywilizacji eurazjatyckiej. Stare tezy eurazjatyckie rozwinięto tu w kategoryczne zalecenia zmiany sposobu wdrażania rozwiązań demokratycznych w FR, przebudowy porządku społecznego, rewizji prawa, m.in prawa do własności prywatnej, przeprowadzenia szeregu reform ekonomicznych dowartościowujących i umacniających rubel rosyjski, a tym samym nadających nowy status i możliwości gospodarce na obszarze eurazjatyckim. Zgodnie $\mathrm{z}$ duchem nowego technokratyzmu ustępy postulatywno-instrukcyjne projektu umieszczone są w kontekście ideowo-propagandowym. Z ideokratycznego punktu widzenia analityków IE ów kontekst jest ważniejszy od przedstawionego programu reform - program wynika z „właściwie wybranej doktryny”. Jedynym zaś prawidłowym wyborem jest restauracja cywilizacji eurazjatyckiej. W projekcie nie ma mowy o zbieraniu ziem Eurazji już to w granicach byłego ZSRR, już to wykraczając poza nie. Mowa o rozszerzaniu przestrzeni eurazjatyckiej i „obrastaniu” FR państwami bliskiej zagranicy. Słowo Eurazja nie występuje, co pozornie oddala doktrynalny fundament projektu od statokratytyczno-imperialistycznych poglądów eurazjatów okresu międzywojnia i dystansuje zarówno od radykalnej tradycjonalistyczno-mistycznej postaci eurazjatyzmu w wydaniu Aleksandra Dugina, jak i „naukowego” obsesyjnie ksenofobicznego i separatystycznego rozumowania Lwa Gumilowa. Analitykom IE zależało, by projekt sprawiał wrażenie osadzonego we współczesnych realiach politycznych. O ile pojęcie przestrzeni eurazjatyckiej - zwłaszcza w kluczowej dla analityków IE perspektywie rozwoju Eurazjatyckiej Unii Gospodarczej - nie może być łatwo zakwestionowane, o ile pojęcie cywilizacji eurazjatyckiej w projekcie, który tytułem już sygnalizuje charakter geopolityczny nie nasuwa natychmiastowych podejrzeń, że dokument jest kolejnym przykładem nacjonalistycznego science fiction, o tyle imperium Eurazji jako idea przewodnia projektu mogłoby nasuwać wątpliwości co do 
jego realizmu i wartości praktycznej. W promowanej doktrynie, która - jak zakładają autorzy projektu musi być wybrana, gdyż jest to jedyny obecnie sensowny wybór - uwaga skupia się na Federacji Rosyjskiej i jej roli w cywilizacji eurazjatyckiej. Rola ta historycznie i geopolitycznie jest centralna, jednak po 1993 roku FR nazbyt uzależniła się od UE i innych „światowych ośrodków władzy”, zatracając częściowo swoje „cechy cywilizacyjne”. Tym samym straciła pozycję eurazjatyckiego centrum cywilizacyjnego. Aby ją odzyskać, musi odbudować powszechne poczucie świadomości odrębności politycznej i kulturowej, i - co nie mniej ważne - uzyskać stabilność ekonomiczną. Dobrze prosperująca gospodarka w oparciu o rosyjskie zasoby naturalne, wzrost demograficzny i podniesienie poziomu życia do standardów Europy Środkowej to tylko pierwszy etap na drodze do suwerenności FR i odnowy potęgi eurazjatyckiej. Następnym powinno być zajęcie miejsca obok innych czterech mocarstw - USA, UE, Chin i Indii. Podczas gdy Tamak żywi nadzieję powrotu do dwubiegunowego układu światowego Rosja-USA, autorzy „Projektu globalnego »Rosja «” widzą przyszłość FR w świecie wielobiegunowym. Najważniejsze, by znów stała się podmiotem konkurencyjnym. Mniemać wypada, iż analityków IE najbardziej interesuje konkurowanie FR w sferze ekonomii. Jak tego dokonać, rezygnując z wszelkich zależności od układów politycznych i wycofując się z rynku światowego? Przyjmując charakterystyczny w nurcie eurazjatyzmu postulat rosyjskiej autarkii (tu: „umiarkowanej”), a jednocześnie starając się uniknąć anachroniczności w pojmowaniu mechanizmów politycznych, autorzy projektu IE popadli w sprzeczność. Sugerowany w projekcie „wybór cywilizacyjny” wskazuje jednocześnie dwa kierunki. Pierwszy z nich nakazuje w duchu Konstantina Leontjewa i Gumilowa odcięcie się od „wirusów” przenoszonych przez obce cywilizacje i budowę imperium eurazjatyckiego w oparciu o prawosławie i chrześcijańską ideę samoograniczenia (integracja i rozwój swoistego Monasteru Rosja"). Drugi - zgodny z założeniami Eurazjatyckiej Unii Gospodarczej - zakłada integrację ekonomiczną i polityczną obszaru postsowieckiego, stworzenie konkurencyjnego wspólnego rynku finansowego, energetycznego i transportowego i włączenie do gospodarki światowej. Abstrahując od logiki i ewentualnych skutków tego podwójnego wyboru, autorzy projektu słusznie podkreślają priorytet wyboru elit rządzących. Ostatecznie ten wybór jest najważniejszy i warunkujący strategie rozwojowe FR.

Nacjonalizm prezentowany przez autorów omawianego projektu jest wybitnie inkluzywny. Rosja nie kończy się w granicach państwa rosyjskiego ani przestrzeni eurazjatyckiej. Za główne kryterium rosyjskości uważają poczucie rosyjskości, 
uznanie FR za swoją ojczyznę i opanowanie języka rosyjskiego w stopniu pozwalającym uważać go za język ojczysty. To wystarczy, by uzyskać obywatelstwo rosyjskie $^{37}$. Wbrew z gruntu słowianofilskiemu przekonaniu, że Rosjanie to ludzie prawosławni, w projekcie IE zakłada się, że przekonania religijne nie mogą być przeszkodą dla tych, którzy czują się Rosjanami i pragną być za nich uznawani. Wprawdzie światopogląd prawosławny jest w Rosji najbardziej tradycyjnym i wciąż najbardziej reprezentatywnym, lecz przecież nie jedynym. Prezentowana tu myśl imperialistyczna wykazuje związki z ekspansjonizmem panslawistycznym Nikołaja Danielewskiego i Fiodora Dostojewskiego - przyszłe granice Rosji mają być rozciągnięte do granic „świata prawosławnego", który obejmie wszystkie państwa nie tylko z religią prawosławną jako wiodącą, ale i te, gdzie istnieją jedynie mniejszości prawosławne. W ten sposób prawosławie, nie stanowiąc czynnika wykluczenia, pozostałoby tradycyjnym w łonie nacjonalizmu rosyjskiego spoiwem i narzędziem ekspansji. W efekcie integracji państw prawosławnych, prawosławnych wspólnot wyznaniowych rozproszonych na całym świecie i osób nie prawosławnych, ale deklarujących rosyjskość autorzy projektu chcieliby, by dokonała się zapowiedziana w tytule projektu globalizacja po rosyjsku ${ }^{38}$. Niezgodnie z tym, co zostało w projekcie umieszczone jako program tożsamy z celami Eurazjatyckiej Unii Gospodarczej i obecną w niej wizją przyszłej pozycji FR na rynku globalnym, jak również bez związku z poglądami Dugina, który pragnie rozwijać federalizm eurazjatycki, w dalszej części projektu zaleca się powrót do unitaryzmu. Romantyczna idea soborowości Rosjan z urodzenia i wyboru zespolona została z przedrewolucyjnym imperializmem wielkomocarstwowym i ekspansjonizmem o proweniencji bolszewickiej. Podziały administracyjno-terytorialne uznano za niepotrzebne. Podkreślono natomiast potrzebę wzmożenia w FR ochrony kultur narodowych. Wielokulturowość zachowano jako element konieczny mocarstwowości lub/i aluzję do błędnej z punktu widzenia analityków EurAzES polityki westernizacyjnej „liberałów”. Jedność wielonarodowego społeczeństwa radzieckiego pozostaje jednym z ważniejszych sowieckich ideologemów, jedność różnych etnosów i kultur jest fundamentem myśli eurazjatyckiej. Nostalgia postsowiecka i eurazjatyzm są autorom projektu równie bliskie. Troska

\footnotetext{
37 Rossija: obraz buduszczego (Miroprojekt „Rosja”), [w:] W. Tamak, op.cit., s. 346.

38 Nacjonaliści rosyjscy, od A. Gułagi i W. Aksjuczica po A. Dugina, często w nawiązaniu do idei wszechczłowieczeństwa Dostojewskiego, głoszą ideę zjednoczenia ludzkości we wspólnej wierze i wokół wartości tradycyjnie rosyjskich. Por. A. de Lazari, Tematy do rozważań nad stereotypami, „Biuletyn Polskiego Instytutu Spraw Międzynarodowych” 2001, nr 4, s. 31.
} 
o zachowanie jedności w różnorodności kulturowej Rosji brzmi fałszywie w zestawieniu ze specyficznym kryterium rosyjskości. Logika projektu każe sądzić, że w miarę postępu ochotniczego patriotyzmu rosyjskiego kultury inne niż rosyjska będą za przyzwoleniem ich rdzennych przedstawicieli przybierać formy reliktowe. Sprzyjać temu będzie promocja języka rosyjskiego, który - obok prawosławia - w projekcie uznano za drugi najważniejszy czynnik integracji regionalnej, a następnie globalnej. Postulowane jest przywrócenie go jako języka urzędowego na terytorium byłego ZSRR i rozpowszechnianie go w Izraelu (zapewne ze względu na istniejącą tam pokaźną diasporę rosyjską). W dalszej perspektywie czasowej miałby uzyskać status urzędowego we wszystkich krajach słowiańskich - w ten sposób będą one mogły zintegrować się wokół Rosji jako ostoi światowej Słowiańszczyzny. Drugim językiem urzędowym FR projektanci widzą język turecki, trzecim - ugro-fińską i centralnoazjatycką wersję słowiańskiego esperanto. Nie mniej zależy im na promocji języka rosyjskiego w Europie Zachodniej, powinien być tam używany na równi z angielskim, niemieckim, włoskim, hiszpańskim i francuskim, poza Europą zajmować winien trzecie miejsce, po języku lokalnym i angielskim. Zwrócenie uwagi na język rosyjski jako czynnik jednoczenia i ważny w promocji państwa symbol jest elementem oryginalnym. Po radzieckiej promocji języka rosyjskiego w ZSRR i krajach Układu Warszawskiego ten motyw we współczesnej rosyjskiej myśli nacjonalistycznej dotąd z taką mocą nie występował. Wskazywanie na instrumenty integracji w kontekście marketingowym (postulat rebrendingu kultury rosyjskiej jako zapoczątkowanie „wielkiego stylu narodowego" ${ }^{39}$ ) nie jest typowe dla nacjonalistów rosyjskich. Typowe natomiast jest nawoływanie do rozwoju demokracji organicznej z dobrze rozwiniętymi samorządami i związkami zawodowymi. Analitycy IE uważają, że rozwój wolnego rynku i własności prywatnej nie powinien obejmować sektorów strategicznych. Ziemia i inne dobra naturalne powinny zostać wycofane z obrotu handlowego, gdyż stanowią własność wszystkich obywateli FR. Szczególnych starań należy dołożyć, by na nowo upowszechniło się tradycyjne od okresu przedchrześcijańskiego do rozpadu ZSRR zmitologizowane myślenie o ziemi rosyjskiej w kontekście wielkomocarstwowego patriotyzmu. Własność prywatna powinna być utrzymana w granicach średniej i drobnej produkcji, handlu oraz usług. W działalności gospodarczej priorytetową rolę powinny odgrywać spółki udziałowe i towarzystwa akcyjne.

39 Rossija: obraz..., op.cit., s. 346. 
Wyraźne nawiązanie do programu „modernizacji bez westernizacji” Dugina ${ }^{40}$ nie pozostawia wątpliwości, że zarówno projekt Tamaka „Modernizacja 2012”, jak i „Globalny projekt »Rosja «” są kolejną próbą reaktywacji i popularyzacji myśli neoeurazjatyckiej oraz nadania jej nośności politycznej. Koncepcje modernizacyjne nacjonalistów skupionych w Instytucie EurAzES w większości stanowią kompilację założeń klasycznego eurazjatyzmu oraz wybranych elementów myśli Gumilowa i Dugina. Świadczą o tym, że eurazjatyzm jako antyzachodnia, antyglobalistyczna, tradycjonalistyczna, nostalgiczno-regeneracyjna wizja obszaru postradzieckiego, Federacji Rosyjskiej i jej usytuowania globalnego jest aktywna i ewoluuje. Do ogłoszenia prac Djewjatowa można było sądzić, że twórczość Dugina wyczerpuje możliwości poszerzenia rezerwuaru ideowego i popularyzacji eurazjatyzmu. Analitycy IE, skupiając się jedynie na wybranych elementach myśli eurazjatyckiej, nie wzbogacili znacząco zasobu ideowego eurazjatyzmu, ale wypracowali nowy sposób jego prezentacji. Słusznie uważając, że erudycja i fantazja Dugina i Djewjatowa nie sprzyjają upowszechnianiu eurazjatyckiego sposobu myślenia we współczesnej Rosji, a tym bardziej nie torują ich eksponentom drogi do Dumy, starają się przenieść myśl eurazjatycką z poziomu teoretycznego na poziom operacyjny. To, co do tej pory było marginalnym przedmiotem zainteresowania elit nacjonalistycznych w FR, umieszczają na płaszczyźnie rozumowania potocznego. Nowatorstwo projektantów przyszłości FR i własnych karier politycznych w duchu „nowego technokratyzmu” sprowadza się do przesunięcia akcentu $\mathrm{z}$ treści doktryny eurazjatyckiej na silnie rozbudowany kontekst jej prezentacji. Kontekst ten wypełnia krytyczne podsumowanie dokonań rosyjskich elit politycznych po 1993 roku.

40 Por. R. Bäcker, op.cit., s. 201. 